\title{
NANOMATERIALS FOR BONE TISSUE REGENERATION AND ORTHOPEDIC IMPLANTS
}

\author{
Gulcihan Gulseren, Melis Goktas, Hakan Ceylan, \\ Ayse B. Tekinay, and Mustafa O. Guler \\ Institute of Materials Science and Nanotechnology, National Nanotechnology \\ Research Center (UNAM), Bilkent University, Ankara, Turkey
}

\subsection{INTRODUCTION}

Bone is a highly mineralized connective tissue with complex biochemical and biophysical cues including structural, compositional, and cellular properties that cooperate to direct bone function and remodeling. Hierarchical organization and specialized composition of bone extracellular matrix $(\mathrm{ECM})$ control the cellular processes including proliferation, migration, and differentiation for continuous modulation and maintenance of structure (Fernandez-Yague et al., 2014). In general, bone tissue consists of inorganic components such as hydroxyapatite and a wide variety of organic components, most of which is type I collagen. Inorganic mineral phase constitutes $65 \%$ of the wet weight of the bone tissue, while the organic components contribute to the rest with water (Triffit, 1980). Organic extracellular components found in bone matrix can be classified as insoluble (e.g., collagen) and soluble (e.g., growth factors (GFs), transcription

Therapeutic Nanomaterials, First Edition. Edited by Mustafa O. Guler and Ayse B. Tekinay.

(C) 2016 John Wiley \& Sons, Inc. Published 2016 by John Wiley \& Sons, Inc. 
factors) factors and play a critical role in bone organization and remodeling (Athanasiou et al., 2000). Organic components, primarily collagen, provide resistance to tension, while the inorganic mineral phase contributes to resistance against compression. When the bone is demineralized, remaining organic phase provides flexibility and resistance to fracture, while removal of organic matrix makes the bone rigid and brittle. As a composite structure consisting of these organic and inorganic components, hierarchically organized bone matrix not only serves as a structural and mechanical support to cells but also provides biochemical cues that regulate cell and tissue functions.

\subsection{BONE MATRIX}

\subsubsection{Organic Matrix and Bioactivity}

6.2.1.1 Insoluble Factors The organic matrix of bone is predominantly constituted by collagens. Collagens, mostly type I along with small amounts of type V and type XII, form $90 \%$ of the organic bone matrix and the rest $10 \%$ is composed of noncollagenous matrix proteins and proteoglycans (Triffit, 1980). Generally, nonmineralized part of the bone is composed of a variety of network organizations including random network of coarse collagen bundles as well as hierarchically organized parallel fibrils and bundles. Type I collagen fibrils are bundled together to form parallel collagen fibers with a large scale in diameter ranging from 0.2 to $12 \mu \mathrm{m}$ (Kielty and Grant, 2002). This specific organization into large diameter parallel fibrils plays the primary role in supporting bone tissue to withstand tensile stress. However, collagen not only provides mechanical strength to bone but also contains short peptide sequences that exhibit bioactive signals such as aspartic acid-glycine-glutamic acid-alanine (DGEA) peptide motif, which can activate adhesion and differentiation of osteoblastic cells and mesenchymal stem cells through interaction with cell surface receptors called integrins (Hennessy et al., 2009; Mizuno et al., 2000).

Bone also contains a wide variety of noncollagenous proteins produced by osteoblasts including osteonectin, osteocalcin, osteopontin, bone sialoprotein (BSP), and small proteoglycans, which play important roles in matrix organization, mineralization, and cellular functions. Bone cells contain a variety of transmembrane receptors such as integrins, cadherins, and selectins. Among these, integrins are the primary receptors regulating the cell-matrix interactions (Hynes, 1992). Through the interaction with ligand motifs such as arginine-glycine-aspartic acid (RGD) adhesion 
sequence present in the structure of many noncollagenous bone matrix proteins, integrin signaling pathways regulate cellular functions including osteoblast survival, gene expression, and matrix mineralization (Garcia and Reyes, 2005).

The most abundant noncollagenous bone matrix protein in mineralized bone is osteonectin. It has been proposed that osteonectin contains calcium and collagen binding domains that act as nucleation sites for hydroxyapatite formation and mineralization (Engel et al., 1987; Maurer et al., 1996; Young et al., 1992). Another calcium-binding matrix protein is osteocalcin, which is also called as bone Gla protein. Due to the acidic residues $\left(\gamma\right.$-carboxyglutamic acid) found in its structure, this protein has a $\mathrm{Ca}^{2+} /$ hydroxyapatite affinity (Ducy et al., 1996). Osteocalcin also acts as a regulator of bone remodeling through suppression of bone formation by osteoblasts and promotion of osteoclast migration (ButLer, 2000). Osteopontin is another acidic glycoprotein found in bone tissue, which is involved in the regulation of mineral deposition and cell migration (de Oliveira and Nanci, 2004). It has been proposed that hydroxyapatite formation is inhibited by the suppression of crystallite growth through high-level phosphorylation and negative charge density of osteopontin preventing ionic growth via electrostatic repulsion of ions (Pampena et al., 2004). Osteopontin also contains cell-adhesive RGD amino acid sequence that provides cell attachment and regulates osteoclast motility and migration during bone resorption (ButLer, 2000; Oldberg et al., 1986). BSP constitutes 15\% of the noncollagenous bone matrix proteins and contributes to bone mineralization and remodeling through facilitation of HA nucleation (Hunter et al., 1996; Wuttke et al., 2001). Also, due to the RGD peptide sequence found in its protein structure, BSP promotes osteoblast adhesion and differentiation (Oldberg et al., 1988).

6.2.1.2 Soluble Factors Bone matrix also contains soluble and mobile biochemical cues synthesized by local osteoblasts or by cells outside of the bone and then delivered to bone matrix via the bloodstream. GFs are a group of these soluble factors, which take place in the regulation of cellular functions such as cell growth, motility, proliferation, differentiation, and bone formation (Mackie, 2003; Urist, 1965). Bone matrix contains a variety of GFs including bone morphogenic proteins (BMPs), transforming growth factor- $\beta$ (TGF- $\beta$ ) family, insulin-like growth factor I and II (IGF-I, IGF-II), fibroblast growth factors (FGFs), and vascular endothelial growth factor (VEGF) (Canalis et al., 1988; Gowen et al., 1983; Hauschka et al., 1986; Mohan and Baylink, 1991; Sporn et al., 1986; Urist et al., 1983). 
BMPs are the only GFs that can stimulate differentiation of mesenchymal stem cells into both chondroblasts and osteoblasts. Therefore, they play a critical role in endochondral bone formation where cartilage forms first and then it is replaced by bone (Wozney and Rosen, 1998). Other GFs such as TGF- $\beta$, IGF, and FGFs take place in the proliferation of already differentiated bone-forming cells and matrix deposition. Also, FGFs and VEGF act in bone formation and remodeling by inducing vascularization (angiogenesis).

In addition to GFs, osteoblasts carry other soluble factors in their matrix in vesicles built from phospholipid membranes, which play an important role in nucleation of hydroxyapatite and mineralization (Bosetti et al., 2005; Eanes, 1989; Raggio et al., 1986). Matrix vesicles contain calcium, phosphorus, and alkaline phosphatase (ALP). ALP functions by hydrolyzing organic phosphate esters and producing free inorganic phosphate, which initiates biomineralization and hydroxyapatite deposition on ECM proteins (Beertsen and van den Bos, 1992; Storrie and Stupp, 2005).

\subsection{INORGANIC MATRIX, MINERALIZATION, AND BONE ORGANIZATION}

The inorganic matrix of bone consists of a mineral phase in the form of carbonated hydroxyapatite crystals (Reznikov et al., 2014). Mineral phase functions as an ion reservoir to keep the extracellular fluid concentrations within the proper ranges for physiological functions and also provides stiffness and strength to bone tissue to withstand the mechanical forces. Bone mineral crystals contain $99 \%$ of the total body calcium, $85 \%$ of the phosphorus, and more than $40 \%$ of the sodium and magnesium (Glimcher, 1992).

Basically, mineralization of bone occurs as a phase transformation of soluble calcium and phosphate found in the organic matrix into solid calcium phosphate crystals. Solid calcium phosphate first forms as a poor crystalline apatite and the crystallinity of bone apatite increases in time (Roberts et al., 1992). Calcification of bone first starts in specific hole regions of the collagen fibrils formed by type I collagen. Hierarchical array structure built by the triple helical molecules of type I collagen results in formation of holes within the fibrils that are further aligned to construct grooves $(1.5 \mathrm{~nm}$ thick) in which the mineral crystals form (Traub et al., 1989). Crystals of carbonated hydroxyapatite nucleate in these grooves as a precursor phase and the growth of crystals extends to include the zone of collagen fibrils between the grooves. Eventually, 
mineral phase deposits all over the space within fibrils and mineralized collagen fibrils in the form of plate-shaped crystal layers are formed (Traub et al., 1992; Weiner and Traub, 1986). Mineralization usually takes place very rapidly so that $60 \%$ of the total mineral capacity is achieved within hours. After the initial phase, mineral concentration, density, and stiffness of bone increase, while the water content and the noncollagenous protein concentration decrease, but the collagen organization and concentration remain the same (Triffit, 1980).

\subsubsection{Mechanical Properties and Structural Hierarchy of Bone Tissue}

Bone tissue is a hierarchically organized connective tissue with specialized structural features, material properties, and cellular organization that direct bone function in an interactive manner. According to its structural organization, porosity, and mechanical properties, bone tissue can be classified as either cortical or cancellous bone. Cortical bone has less than $20 \%$ porosity and a specialized compartmentalized organization that consists of closely packed osteons and cylindrical systems called Haversian canals with a central channel enclosing a blood vessel surrounded by concentric rings (lamellae) of bone matrix (Fernandez-Yague et al., 2014). Macroscale organization of this compartmentalized system provides a characteristic mechanical anisotropy to long bones. According to the direction of applied force, mechanical stiffness of the cortical bones differs. When a force is applied along the Haversian canals, the elastic modulus of the system can be measured as approximately $E=20 \mathrm{GPa}$, while it can be altered to $8 \mathrm{GPa}$ along the transverse axis (Katsamenis et al., 2013). Cancellous bone (spongy bone) is more porous ( $>90 \%$ porosity), softer, and flexible than cortical bone. However, mechanical stiffness of cancellous bone is more isotropic depending on the density and porosity of the trabeculae and can change depending on the loading rate. Elastic modulus of cancellous bone can vary between 50 and $100 \mathrm{MPa}$ (Beddoe et al., 1976; Goldstein et al., 1983). Bone cells including osteocytes, osteoblasts, osteoclasts, and osteoprogenitor cells are able to sense the mechanical properties of their environment and the mechanical stress arising from physical loading during skeletal movement, and they produce cellular biochemical responses via integrin-mediated mechanotransduction to maintain bone remodeling (Sikavitsas et al., 2001). Therefore, in order to properly simulate the mechanical physiological environment in natural bone tissue, design of a scaffold should comprise similar mechanical properties as well as the hierarchical organization of native bone since the factors such as porosity could compromise the mechanical competence of the material. 


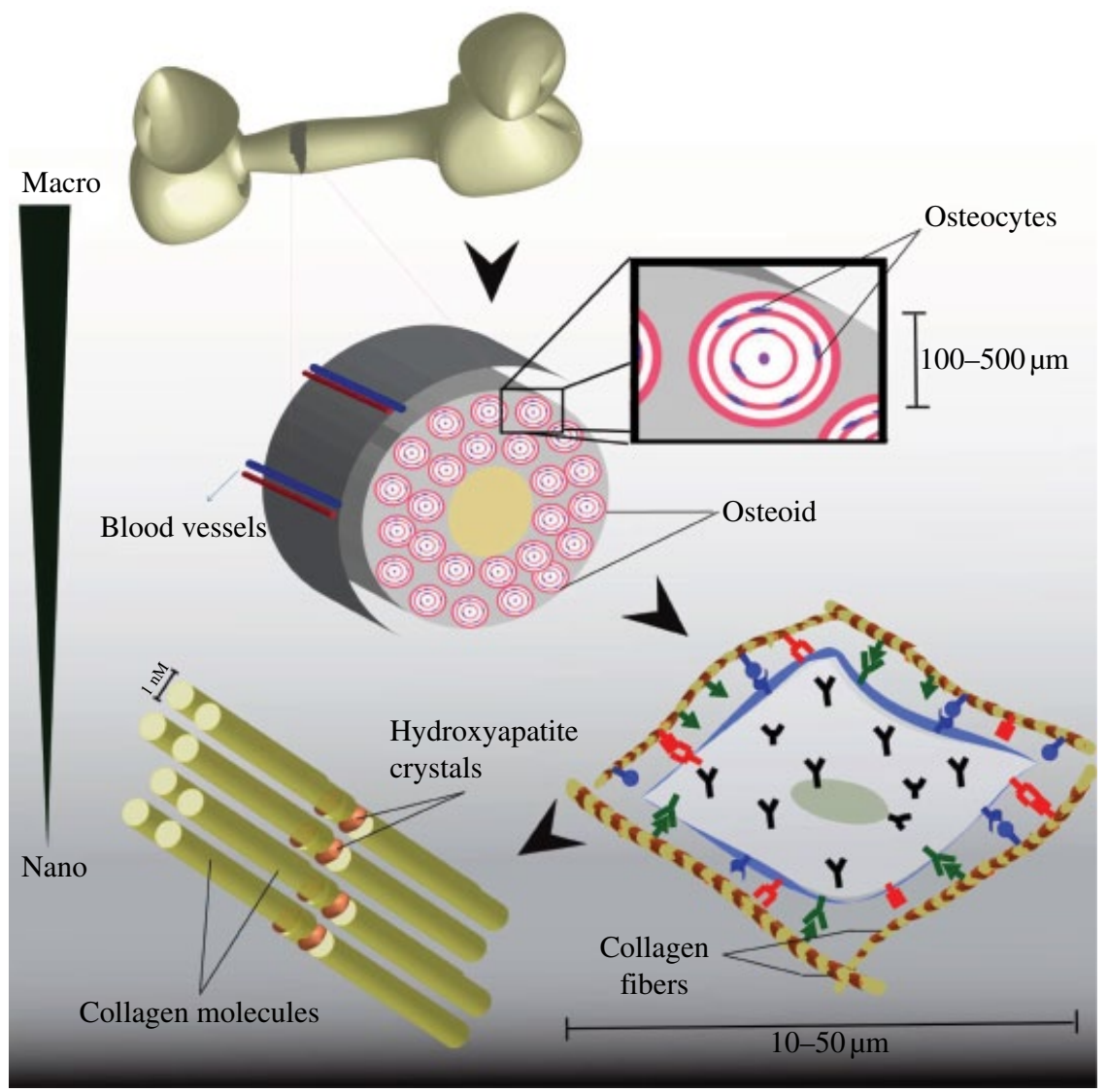

FIGURE 6.1 Hierarchical organization of bone from macro- to nanoscale.

Macro- to nanoscale hierarchical structure and porosity of the bone are also important at cell-material interface in terms of regulating mineralization, vascularization, and cellular functions such as proliferation, migration, and ECM production (Fig. 6.1). Macroscale porosity ( $>400 \mu \mathrm{m}$ ) and interconnectivity of pores promote osteogenesis by enabling cell migration, vascularization, nutrient transportation, and waste disposal. Micro- and nanoscale architectures also serve as a cell and mineral binding template. Organization of type I collagens into fibers with diameters of 3-10 nm and lengths of $300 \mu \mathrm{m}$ supports the binding of nanoscale hydroxyapatite crystals (10-50 nm long) and proteins. Cell adhesion and mineral nucleation directed by microscale collagen template contribute to the resilience and strength of bone tissue (Mistry and Mikos, 2005; Nair et al., 2013). 


\subsection{REGULATION OF BONE MATRIX IN ADULT TISSUE}

Bone is a rigid but dynamic living tissue that continuously undergoes remodeling and regeneration to maintain its structural integrity and function. Angiogenesis plays an important role in bone remodeling as well as in fracture healing. Vasculature supplies bone tissue with oxygen, nutrients, GFs, hormones, and cytokines as well as osteoblast and osteoclast precursor cells, which are important for bone remodeling processes, and also provides communication between bone and neighboring tissues (Chim et al., 2013; Kanczler and Oreffo, 2008).

Bone remodeling occurs in two important steps accomplished by osteoclasts and osteoblasts. Osteoclasts perform bone resorption by removing old and damaged bone through degradation of bone matrix. Then, mineralization and deposition of new bone matrix are carried out by osteoblasts in the resorption area. This process takes place in specialized vascularized structures called bone remodeling compartments (BRCs) (Hauge et al., 2001). BRC is a narrow sinus formed between the bone marrow and the remodeling surface, which contains osteoclasts, osteoblasts, osteocytes, bone lining cells, and the capillary blood supply. BRC serves as an anatomical structure that couples the blood supply with bone remodeling process. Osteoblast and osteoclast precursor cells as well as cytokines and systemic hormones are recruited to the remodeling site via circulating blood supply. BRC also facilitates the direct cell-to-cell contact between osteoblast and osteoclast precursors since the secretion of membrane-bound receptor activator of NF- $\mathrm{\kappa B}$ ligand by osteoblasts is required for differentiation and activation of osteoclast precursors, which enter the BRC through the blood supply to start the remodeling process (Yasuda et al., 1998).

The initial stage of bone remodeling after a stimulus such as an injury is the formation of new blood vessels connecting the BRC to the existing vasculature. Early vascularization and blood flow to the injured site are essential for a proper healing and osteogenic repair since vessels provide nutrients and other factors required for the regeneration process (Fang et al., 2005). Previous studies demonstrated that angiogenesis takes place before the initiation of osteogenesis and the formation of new blood vessels is crucial for the transport of osteoblast and osteoclast precursors to remodeling sites (Sojo et al., 2005). Therefore, the intercellular communication between bone-forming cells and vessel-forming endothelial cells plays an important role in remodeling and regeneration of bone tissue. Communication between these cell types is conducted by direct or indirect cell contact and by the secretion of diffusible factors. It has been indicated that the diffusible factors produced by osteoblasts and osteoclast affect 
endothelial cell functions such as proliferation, survival, migration, and angiogenesis (Brandi and Collin-Osdoby, 2006). Recent studies demonstrated that osteocytes also play an important role in the initiation of remodeling process by secreting angiogenic factors including RANKL, VEGF, and BMPs (Chim et al., 2013).

\subsubsection{Angiogenic Factors in Bone Remodeling}

A large variety of angiogenic factors such as VEGF, FGF, BMPs, TGF- $\beta$, and platelet-derived growth factor (PDGF) are involved in bone remodeling process. Among these, VEGF is a potent mitogen and angiogenic factor for endothelial cells and it serves as a central regulator for the other diffusible factors. At the initial stage of bone remodeling, VEGF plays an important role in the formation of new blood vessels since it regulates the mobilization of endothelial progenitor cells, their differentiation into endothelial cells, and proliferation (Ferrara et al., 2003). VEGF also acts as a strong chemoattractant for osteoblasts and osteoclasts and supports their survival (Henriksen et al., 2003; Mayr-Wohlfart et al., 2002). It has been reported that inhibition of VEGF blocks angiogenic activity of FGF and BMP-2. Blocking of BMP-2 activity in turn results in inhibition of osteoblast differentiation and bone formation (Deckers et al., 2002; Peng et al., 2005). It has been reported that the inhibition of VEGF prevents in vitro osteoblast differentiation, while its in vivo inhibition results in decreased blood vessel formation and osteoclastic activity during bone remodeling, as well as reduced mineralization and trabecular bone healing (Gerber et al., 1999; Maes et al., 2002, 2004; Street et al., 2002).

FGF is another angiogenic factor produced by various cell types including fibroblasts, endothelial cells, and osteoblasts (Globus et al., 1989; Montero et al., 2000; Sato et al., 1991). FGF stimulates angiogenesis via inducing endothelial cell proliferation and migration and increases expression of GFs and integrins involved in angiogenesis (Klein et al., 1993; Seghezzi et al., 1998). It also induces osteogenesis through promoting proliferation of osteoblast precursor cells and their differentiation into mature osteoblasts (Hanada et al., 1997; Pitaru et al., 1993).

BMPs including BMP-2, BMP-4, and BMP-7 also play important roles in promotion of angiogenesis and osteogenesis. BMPs stimulate the proliferation and differentiation of MSCs and osteoprogenitor cells to promote bone regeneration (Bax et al., 1999; Fiedler et al., 2002; Lee et al., 2006; $\mathrm{Li}$ et al., 2005). They also induce endothelial cell proliferation, migration, and angiogenesis (David et al., 2009). 
Both TGF- $\beta$ and PDGF are known to be potent chemoattractants produced by degranulating platelets at the injury site. TGF- $\beta$ serves as a chemoattractant for MSCs and it promotes differentiation of osteoblasts (Erlebacher et al., 1998; Tang et al., 2009), while PDGF is known to be a chemoattractant and mitogenic factor for osteoblasts at the bone remodeling sites (Mehrotra et al., 2004). TGF- $\beta$ also induces VEGF expression in endothelial cells within the BRC to increase blood supply during remodeling process (He and Chen, 2005; Shao et al., 2009).

\subsection{STRATEGIES FOR BONE TISSUE REGENERATION}

\subsubsection{Hard Grafts for Bone Regeneration}

Bone implants are medical devices used to replace or fix injured bone parts for a temporary period of time or permanently. They are used extensively in dental, maxillofacial, and orthopedic surgeries (Dohan Ehrenfest et al., 2010; Smalley et al., 1988; Yeo, 2014). Bone anchoring is also an integral part of cochlear and spinal implants and artificial limbs (Gittens et al., 2014; Khan et al., 2012; Wazen et al., 2007). Global estimates suggest that more than 12 million patients receive oral implants and around half a million patients undergo hip replacement surgery per annum (Albrektsson et al., 2014; Hoption Cann et al., 2003; Mundi et al., 2014). As these devices are designed to bear and transfer mechanical loads, tight and stable bone bonding is essential for long-term functioning. In this regard, understanding and directing complex interactions occurring at the bone-implant interface has critical implications for developing effective healing strategies. When an implant comes into contact with the native bone, there are two possible outcomes. If the bone-implant interface is properly filled with a bone-like mineral, biological bone bonding, that is, osseointegration, is established. Coined first by Brånemark, osseointegration is the clinically desired state of healing where no progressive relative movement between the implant and bone tissue is observed under mechanical loading (Adell, 1985; Branemark et al., 2001; Khan et al., 2012). If this process is delayed or permanently fails, the interface is instead filled with a collagenous, nonmineralizable soft matrix, which isolates implant from the rest of the body, leading to implant failure (Le Guéhennec et al., 2007; Southam and Selwyn, 1970). In this case, a revision surgery becomes inevitable, which is usually more expensive and invasive, with increased risk factors compared to the primary intervention (Vanhegan et al., 2012). On the one hand, remarkable progress has been made over the last four decades in the 
understanding of short- and long-term contributors to bone bonding and functioning. Recent clinical surveys suggest that the long-term success rates are above $80 \%$ for various types of implants (Melo et al., 2006; Penarrocha-Diago et al., 2012; Simonis et al., 2010). On the other hand, there remain a number of major challenges associated with unsuccessful osseointegration, or failure in the longer period. Among the failed implants, the majority is early term failures caused by softening (Penarrocha-Diago et al., 2012). Particularly in patients with impaired osteoblastogenesis, such as osteoporosis, mineralization process takes much longer time and is more prone to failure (Alghamdi et al., 2013). This and other factors that impair the osseointegration process and long-term functioning of bone-anchored prosthetic devices are discussed in detail in the following. Current accomplishments to overcome such challenges are highlighted along with prospective technologies that would have profound impact on the recovery time and the overall life quality of patients.

After implantation of a bone-anchored prosthesis, formation of a tight, mineralized interface is vital for stable osseointegration. This process is under competitive pressure from fibrosis progression, and hence softening, so accelerated osteoblast activity is needed for proper mineralization (Daculsi et al., 1990; Lavenus et al., 2010; LeGeros, 2008; Yuan et al., 2010). Bone implants are made mainly from titanium and cobalt-chromium (molybdenum) alloys due to their suitable mechanical properties and corrosion resistance (Le Guéhennec et al., 2007; Linder, 1989; Mavrogenis et al., 2011). In terms or bioactivity, however, these materials are inert, that is, not osteoinductive, thereby requiring an additional bioinstructive support to promote osteoblast activity. As a result, the main challenge in the field is to define the toolbox of engineering implant surface so as to impart bioactivity for promoted osteoblast activity and osseointegration. However, the irreproducible complexity of dynamic interactions regulating osteoblast formation and subsequent biomineralization has limited the existing efforts to reductionist approaches where one or few bioactive components are displayed on the implant surface, endowing with a competitive advantage for the desired regenerative response. To understand mechanistic relations of surface parameters with osteoblast behavior and bone formation, various in vitro, that is, cell culture, and in vivo, that is, animal, models have been developed. Primary osteoblasts, preosteoblastic cell lines, and progenitor stem cells obtained from mice, rats, and humans have provided invaluable insight into the molecular biology of the biomineralization process (Ceylan et al., 2012, 2014; Fratzl-Zelman et al., 1998; Kalajzic et al., 2005; Kocabey et al., 2013; Marinucci et al., 2006; OlivaresNavarrete et al., 2008; Qi et al., 2003; Wang et al., 2014). Early studies 
toward this purpose concentrated on exploiting topography and wettability of the implant surface to modulate surface free energy at local sites and thereby altering the adsorbed matrix protein profile, that is, conformation, orientation, and composition, from the biological fluids (Arima and Iwata, 2007; Chug et al., 2013; Marinucci et al., 2006; Ruardy et al., 1995; Song and Mano, 2013; Sousa et al., 2008). Interaction of cells with the implant surface through this adsorbed layer of proteins strongly influences early adhesion, spreading, viability, proliferation, and differentiation (Chug et al., 2013; Wilson et al., 2005). For example, the presence of micrometerscale surface roughness promotes higher osteoblast activity compared to the smooth surface (Gittens et al., 2014; Puleo and Nanci, 1999; von Wilmowsky et al., 2014). Then again, the actual method of choice for creating roughness has varying impacts on certain osteoblast behaviors. Both micro- and macrosand blasted surfaces promote cell proliferation, whereas osteoblast differentiation is induced only by macrosand blasting (Marinucci et al., 2006). Osteoblasts can also discriminate micro- and nanoscale topographic features (Olivares-Navarrete et al., 2014). Nanoscale roughness can induce differentiation of mesenchymal stem cells into mature osteoblasts and promotes osseointegration (Aboushelib et al., 2013; Bjursten et al., 2010; Mendonca et al., 2009). In addition to its direct impact on osteoblast functionality, roughening also provides greater surface area for primary bone bonding. For this reason, the majority of commercial bone implants are manufactured to have a roughness of about $1-2 \mu \mathrm{m}$, which leads to an approximately sixfold increase in the total surface area (Albrektsson and Wennerberg, 2004; von Wilmowsky et al., 2014). It is also noteworthy that the minimum bone ingrowth pore size on a material surface is approximately $50 \mu \mathrm{m}$, which implies that osseointegration is established over a much less part of the actual implant surface area (Bobyn et al., 1980). The impact of surface wettability on osteoblast behavior and osseointegration is rather vague. Several reports have linked increase in implant hydrophilicity to enhanced osteoblast functioning and osseointegration (Ceylan et al., 2012; Schwarz et al., 2009). However, depending on the actual surface chemistry, hydrophilicity might not be a striking factor for establishment of osseointegration or it can even be associated with the decrease in osteoblast adhesion in vitro (Unal Gulsuner et al., 2015; Vasak et al., 2014). Hydroxyapatite mineral coating is another strategy to accelerate mineralization at the bone-implant interface. Depending on the micro- and nanoscale geometry and porosity, hydroxyapatite can exhibit osteoinductivity in addition to its osteoconductive properties (Chien and Tsai, 2013; LeGeros, 2008). In this regard, precipitation of carbonated biological apatite on the implanted material would be a useful platform for promoting adhesion, 
survival, and osteogenic differentiation of the progenitor cells (Ceylan et al., 2014; Layrolle, 2011; LeGeros, 2008). Altogether, the interplay between different topographic features with varying surface chemistry and wettability represents a complex state of understanding, which requires more detailed investigation to develop optimal surface parameters for osteoblast behavior and stable osseointegration. Nevertheless, indirect modulation of surface bioactivity through altering the surface free energy is ultimately limited by the lack of selectivity for promoting adhesion of particular cell types, such as osteoblasts with respect to fibroblasts. Reconstitution of artificial microenvironments by means of ECM-mimetic, synthetic cues to direct cellular activities in a controlled way can provide effective guidance for osseointegration through adhesion, growth, and differentiation of osteoblasts and their progenitor cells. Targeting molecular level interactions through cell surface receptors has recently drawn broad attention. For example, a simple tetrapeptide, Asp-Gly-Glu-Ala (DGEA), derived from collagen type I $\alpha 1$ chain, can induce osteogenic differentiation of human mesenchymal stem cells and mouse preosteoblastic cells via binding to integrin receptor $\alpha 2 \beta 1$. Presentation of this molecule on a solid support is critical in differentiation, adhesion, spreading, migration, and proliferation of human mesenchymal stem cells (Anderson et al., 2009b; Ceylan et al., 2014; Hennessy et al., 2009; Mizuno et al., 2000; Mizuno and Kuboki, 2001; Popov et al., 2011; Staatz et al., 1991; Yoo et al., 2011). In this approach, selecting proper cues is the crucial step to modulate desired biological response. For example, a well-established biomimetic tripeptide, Arg-GlyAsp (RGD), of fibronectin interacts with integrin $\alpha 5 \beta 1$, which is critical for adhesion and proliferation, while not having any impact on osteogenic differentiation (Hennessy et al., 2009; Olivares-Navarrete et al., 2008; Yoo et al., 2011). Furthermore, being a rather "universal" cell-adhesive molecule, RGD can also promote adhesion and growth of fibroblasts, which potentially promote fibrosis (Anselme, 2000; Gailit et al., 1997; Shu et al., 2004). In addition to the biochemical identity, surface density, spatial availability, and patterning are the other principal parameters determining the overall cellular response. For example, a threshold density of RGD ligand is necessary on a polymer substrate to induce focal adhesion of osteoblasts (Chollet et al., 2009). Nanostructuring of bioactive cues has been sought as an appealing method for increasing their display density and optimal presentation geometry to the cell surface receptors (Anderson et al., 2009a and 2009b; Englund et al., 2012; Lim et al., 2009; Niece et al., 2003; Silva et al., 2004; Yoo et al., 2011). Self-assembled peptide nanofibers have attracted special attention for this purpose because of their inherent biocompatibility and chemical versatility (Cui et al., 2010; 
Hartgerink et al., 2001; Zhang, 2003). Controlled assembly of chemically well-defined building blocks further allows combinatorial display of multiple cues. Nevertheless, one major drawback of the strategy relying on the modification of implant surfaces with biomimetic cues is the adhesion chemistry that is applied in the form of a robust coating. Water molecules, dissolved ions, and polyionic biomolecules in the biological fluid as well as mechanical abrasiveness during implant placement create a challenging environment for adhesives to operate efficiently (Ceylan et al., 2013). To overcome this challenge, natural adhesives adapted to living underwater provide a plethora of inspirations toward developing biologically safe and reliable synthetic adhesives for medical applications. Mussel-inspired surface functionalization has been proposed a viable alternative for biofunctionalization of implant surfaces (Black et al., 2012; Ceylan et al., 2011, 2012; Kang et al., 2012; Lee et al., 2007). As discussed in detail in Chapter 8, development of a biomedical adhesive is of paramount importance in developing robust implant coatings. Combining the aforementioned strategies, recapitulation of a synthetic matrix coating comprised from a bioactive Lys-Arg-Ser-Arg (KRSR) sequence known to selectively bind and promote osteoblastic cell behaviors over fibroblasts, as well as from mussel-mimetic adhesive moiety, Dopa, represents one of the stateof-the-art approaches (Nelson et al., 2006).

In summary, a complex variety of parameters create an array of interactions at the bone-implant interface, the outcome of which has an integral role on the establishment of osseointegration. The aforementioned factors constitute a useful toolbox in the form of source of inspiration for guiding cellular behavior toward efficient bone bonding as well as aspiration for the prospective strategies.

\subsection{SOFT GRAFTS FOR BONE REGENERATION}

Native bone tissue is mainly a nanocomposite structure with physical and biological features guiding osteoinductive and osteoconductive properties. For bone tissue regeneration, peptide- or polymer-based biomaterials have offered a framework to design interactive molecules displaying bone composite properties to mimic living bone tissue. Biomimetic peptide and polymer materials can enable the appropriate matrix environment for bone regeneration, integrate desirable biological properties, and provide controlled release of multiple soluble factors or GFs during regeneration process. In the following, structure and properties of peptide-and polymer-based soft grafts for bone tissue regeneration will be reviewed with a summary 
of upcoming goals and challenges in the future of these versatile materials. This section basically covers types and applications of soft bone grafts, directed bone regeneration from biocompatible and bioactive biomaterials, and nanocomposite scaffolds for bone tissue regeneration.

\subsubsection{Peptide-Based Bone Grafts}

Degradable small molecules emerged as an alternative approach for developing implantable materials for tissue regeneration. Bone regeneration studies have been primarily focused on polymers and synthetic proteins. However, these structures have several shortcomings like toxic preparation components (monomers, cross-linking agents, etc.), shrinkage after application, and low biodegradability. Various types of supramolecular nanostructures and hydrogels attained great interest in regenerative medicine because of their significant features, such as simple production, complete biodegradability, and biocompatibility. These inert nanostructures can be applied to deformed bone tissue as implantable or injectable materials with simple procedures and minimal invasiveness. Investigation of selfassembled peptide nanostructures is a growing field with great potential to generate new, facile, and effective bone regenerative applications. Here, we describe some of the significant contributions to the field of bone regeneration with self-assembled peptide structures.

Bone formation is a well-orchestrated and complex biological process; therefore, bone regeneration strategies should meet rigid requirements to constitute proper remodeling of deformed site. During bone regeneration, osteoinduction and osteoconduction are governed by different factors (mechanical, biological, and chemical) that interplay each other, and these components should be considered carefully while constructing materials for bone regeneration. While a diverse set of materials have been utilized to build such scaffolds, inert and mechanically supportive metals and alloys have so far been used as permanent bone implants. These metallic implants and surface modification techniques lack osteoinductive properties, despite their success in osteoconductive features to accelerate the bone healing process. To improve cell attachment and to induce bone differentiation process, bioactive molecule (ECM proteins, GFs) attachments to implant surfaces are critical to obtain adequate bone healing and controlled mineralization. Proteins and GFs are large molecules bearing short peptide sequences, which can trigger downstream processes, especially cell adhesion and differentiation among many other roles. Accordingly, peptide structures with short bioactive units draw significant attention for bone remodeling studies. 
In general, bioactive short peptides are cell-binding epitopes including RGDS, IKVAV, and YIGSR. The RGDS sequence has been frequently used to direct cell attachment. The RGD is found in fibronectin, osteopontin, and sialoprotein, and fibrous materials that display RGD can mimic protein function (Puleo and Bizios, 1991; Pytela et al., 1987). In early studies, adhesion of bone marrow-derived stem cells was investigated on RGDS-containing peptide amphiphile (PA) surfaces, and activity of scaffold was compared with epitopefree peptides. Stem cells were encapsulated into PAs and the coassembled system was injected in vivo. RGDS-containing PA gels promoted cell viability notably better than epitope-free control group (Guler et al., 2006).

The primary component of bone ECM is collagen I fibers, and bioactive short sequences derived from this protein are preferential targets for induction of bone tissue remodeling. The most studied collagen I epitope, DGEA, is found in its $\alpha 1$ helix, and its osteoinductive characteristics were utilized intensively for bone regeneration studies. For example, DGEA peptide-coated hydroxyapatite surfaces enhanced differentiation of mesenchymal stem cell into osteogenic fate (Harbers and Healy, 2005). However, in some cases, bioactivity is not enough for adequate regeneration, and more than one component may be required to enhance activity. For example, another study using CGGDGEAG sequence reported lack of adhesion by rat calvarial osteoblasts onto peptide surfaces (Anderson et al., 2011). To improve adhesion and osteoinductive potential of DGEA-PA, RGDS-PA, and S-PA peptides was utilized with different combinations. According to histochemical staining and PCR results, the RGDS-PA and DGEA-PA combination upregulated osteogenic differentiation (Anderson et al., 2009b). Another short peptide sequence adopted from collagen is GFOGER peptide, which binds to osteogenesis regulating integrin $\alpha 2 \beta 1$. Differentiation of osteoprogenitor cells into osteoblasts can be triggered by using this sequence, and GFOGER-coated polycaprolactone scaffolds were shown to support remodeling of critical-sized defects in rat bone. GFOGER sequence induced significant regeneration in nonhealing femoral defects compared to peptide-free control groups (Dee et al., 1998).

In addition to cell attachment and proliferation, peptide sequences were also used as GF binding units. Binding units located onto gel scaffold can attract GFs to the desired location to sustain improvement during healing process. A well-known bone differentiation-regulating factor, bone morphogenetic protein-2 (BMP-2), which plays significant roles during osteogenesis, was targeted for this purpose. BMP receptor-binding peptides with osteopromotive domains, DWIVA and $\mathrm{A}_{4} \mathrm{G}_{3}$ EDWIVA, were adequate for maintaining bone regeneration process (Gelain et al., 2006). In the ECM, glycosaminoglycans also interact with BMP-2 and sulfated GAG-mimetic peptide-BMP interaction was used to promote osteoblast maturation and 
mineralization of osteogenic cells. The GAG-mimicking ability of the peptide nanofibers and their interaction with BMP-2 promoted osteogenic activity and mineralization of osteoblastic cells (Webber et al., 2010).

RADA16-I is another scaffold that shows stable beta sheet formation, and these peptides can be used with different active groups to form nanostructures to enhance tissue regeneration. In one study, RADA16-I was linked to variable bioactive signal inducing short peptides like ALK (ALKRQGRTLYGF) osteogenic growth motif, DGR (DGRGDSVAYG) osteopontin-based cell adhesion sequence, and PGR (PRGDSGYRGDS) two-repeat RGD adhesion sequence to enhance osteogenic differentiation and support (Horii et al., 2007).

Mussel-inspired Dopa-mediated surface adhesion strategy was applied to direct efficient osteoblast maturation on implant surfaces. For this purpose, $\mathrm{E}_{3}$-PA/Dopa-PA and DGEA-PA/Dopa-PA combination was used to induce osteoblast formation and subsequent bone-like mineralization. Hydroxyapatite-boosting glutamic acid and Dopa residues on fiber surfaces induced significant osteogenic activity as a consequence of significant mineral deposition, since inorganic materials like hydroxyapatite minerals can also induce osteoblast maturation during bone formation process (Tashiro et al., 1989). Therefore, mineral-inducing peptide scaffolds have important roles for bone remodeling studies.

Peptide-based soft bone grafts can also serve as structural frameworks. These materials can be designed in order to have structural components presenting a complementary effect to signaling epitope to enhance bioactivity. For example, micropatterned RGDS-modified scaffolds bearing 20-40 nm holes upregulated osteogenic marker expression compared to nonpatterned surfaces. The hole-patterned surfaces presented high-density epitopes that were able to enclose cells and stimulated differentiation (Sur et al., 2012). In another example, phosphoserine-bearing peptide amphiphile nanofibers were used to induce mineralization. This matrix presented convenient template for hydroxyapatite crystal (HA) — basic bone mineraldeposition as a result of its suitable structure for crystal packing (Anderson et al., 2009b). By the virtue of allowing nanopatterned structure design, peptides are versatile building blocks for generating templates that can induce inorganic material deposition.

\subsubsection{Polymer Nanocomposites as Bone Grafts}

Bone autografts and allografts are already widely used in clinical practice for bone regeneration studies. However, these grafts are not ideal scaffolds for osteogenesis, especially because of biocompatibility and handling 
issues. Producing demineralized bone scaffolds to regenerate native bone tissue requires tedious work, and mineralization of these grafts can be less controllable compared to synthetic scaffolds. These shortcomings of autografts and allografts boosted the interest in utilization of synthetic polymer scaffolds as another useful strategy for bone regeneration. Polymers can be constructed from various building blocks depending on the desired outcome and can be connected or decorated through covalent/noncovalent linkages to create ordered composite.

Biodegradability and biocompatibility are important parameters for bone engineering applications. Natural polymer scaffolds are basically derived from collagen, gelatin-like proteins, or alginate-, hyaluronate-, and chitin-like polysaccharides. However, despite their biocompatibility or biodegradability, these molecules have several shortcomings. These natural constructs were shown to exhibit variable physical characteristics for each batch, such as molecular weight, crystallinity, polydispersity, degradation kinetics, structure, etc., which causes different scaffold properties. On the other hand, synthetic polymeric materials (poly (glycolic acid) (PGA), poly(lactic acid) (PLA)) and their copolymers offer facile and more controllable methods for clinical bone regeneration applications.

Aliphatic polymers were the earliest examples of polymers that were used in the field of bone tissue engineering. PLA, PGA, and poly(lacticco-glycolic acid) (PLGA) and their copolymers are well-known aliphatic polymer types. The most widely utilized subtypes of these polymers are D-PLA PDLA, L-PLA (PLLA) forms of PLA, and blend of D, L-PLA (PDLLA), PLA, PGA, and PLGA, especially used in bone fixation devices, sutures, drug carriers, and bioregeneration scaffolds. In addition to aliphatic polymers, high-molecular-weight aliphatic polyesters, poly(L-lactide), PLA, and PCL, are also used for similar regeneration applications. There are also amorphous polymers, poly(orthoesters), which are hydrophobic and $\mathrm{pH}$-sensitive structures. Poly(orthoesters), like $\mathrm{pH}$-sensitive polymers, are especially used as drug delivery systems, because of enabled $\mathrm{pH}$-responsive degradation that can lead to controlled drug release for medical studies.

Mineralization is a crucial part of bone formation and $\mathrm{CaP}$ minerals are the building blocks of bone composite; hence, mineral-inducing matrices are important for osteogenesis process. During natural bone formation, collagen I fibrils serve as a template upon which HA deposition occurs to form crystalline bone material. Collagen matrix comprises anionic proteins that are nucleator and inhibitor of mineralization, and density of these proteins changes according to bone type or age for controlling deposition (Kocabey et al., 2013). Accordingly, anionic polymers are used to mimic mineralizable collagen matrices for bone mineral nucleation (Palmer et al., 2008). 
For polymer-based mineralization studies, simulated body fluid (SBF), which mimics human plasma in terms of ion concentrations, is a widely applied solution to evaluate ex vivo mineral deposition. Synthetic PLGA and poly-L-lactic acid (PLLA) are early examples of scaffolds mineralized in SBF. Mineralized PLGA polymer construct implanted in a mouse calvarial defect and after 4 weeks showed bone mineral growth, whereas nonmineralized scaffolds did not induce any mineralization (Ceylan et al., 2014). Polymers can also be utilized by mixing with biomolecules; in one example, PLLA mixed with collagen I and SBF closely mimicked natural bone mineral nucleating surface (Mata et al., 2009).

Different monolayers such as dihydrogen phosphate $\left(\mathrm{PO}_{4} \mathrm{H}_{2}\right)$, carboxylic acid $(\mathrm{COOH})$, and methyl $\left(\mathrm{CH}_{3}\right)$ were also investigated for mineralization, and it was found that negatively charged groups are potent inducers of mineralization, where noncharged methyl monolayer did not induce mineralization (Chen et al., 2006; Cowan et al., 2004). Moreover, different monolayers showed different $\mathrm{Ca}: \mathrm{P}$ ratios and different crystal morphologies, meaning that mineral phase is highly dependent charged groups on templates. Charge-functionalized surface moieties induce interaction between fibronectin and functional groups, and this cooperation attracts integrin binding by osteoblasts and probably simulates integrin binding to induce cell-dependent mineralization. In one example of anionic groupfunctionalized polymer, carboxymethyl attached to poly(2-hydroxyethyl methacrylate) (PHEMA) hydrogels displayed better mineralization and cell spreading compared to only PHEMA surfaces after incubation with SBF (Tanahashi and Matsuda, 1997).

Phosphorus is one of the most effective mineralization-inducing chemical units, among the other effective groups. The main role of phosphate ion is stabilization of calcium ions on the polymer surfaces. Phosphatemodified polymers mineralize faster both in in vivo and in vitro conditions (Filmon et al., 2002). Addition of these chemical units also enhances properties of polymers such as vinylphosphonic acid (VPA), which showed better swelling, protein uptake, and adhesion and proliferation of osteoblast (Tan et al., 2005). In another study, PLGA films stabilized and used for enhanced mineralization by the attachment of phosphate ion (Cowan et al., 2004).

Poly(ethylene glycol) (PEG) polymer is one of the most widely used polymers for regenerative studies. Phosphoester-containing PEG hydrogels demonstrate unique characteristics, where polymer backbone allows cleavage of phosphate group by ALP enzyme (Stancu et al., 2004). This material has shown osteoinductive and osteoconductive features by both its phosphate source and phosphate-modified surface characteristics. 
However, some of phosphorus-deficient polymer materials are also capable of surface mineralization like phosphorus-containing analogs. Poly(phosphazene)-based composites interacted with hydroxyapatite due to surface hydrolysis, hydrolyzed carboxylate groups on polymer chain, and nucleated hydroxyapatite layer by interacting with $\mathrm{Ca}$ ions in the surrounding environment ( $\mathrm{Li}$ et al., 2006).

TABLE 6.1 Short Peptides for Bone Regeneration

\begin{tabular}{|c|c|c|c|}
\hline Peptide & Origin & Applications & Reference \\
\hline RGDS & $\begin{array}{l}\text { Found in ECM } \\
\text { proteins, mostly } \\
\text { in fibronectin and } \\
\text { binds to integrin }\end{array}$ & $\begin{array}{l}\text { Cell adhesion, attach cells to } \\
\text { the bioactive surface for } \\
\text { osteogenic activity }\end{array}$ & $\begin{array}{l}\text { Webber } \\
\text { et al. } \\
(2010)\end{array}$ \\
\hline IKVAV & Laminin & $\begin{array}{l}\text { Cell adhesion, spreading, } \\
\text { migration }\end{array}$ & $\begin{array}{l}\text { Tashiro } \\
\text { et al. } \\
\text { (1989) }\end{array}$ \\
\hline YIGSR & Laminin & Cell adhesion & $\begin{array}{r}\text { Sur et al. } \\
(2012)\end{array}$ \\
\hline DGEA & Collagen type I & $\begin{array}{l}\text { Osteoblast-specific binding } \\
\text { via } \alpha 2-\beta 1 \text { integrin }\end{array}$ & $\begin{array}{l}\text { Anderson } \\
\text { et al. } \\
\text { (2009b) }\end{array}$ \\
\hline GFOGER & Collagen IV & Collagen-mimetic sequence & $\begin{array}{l}\text { Zhang } \\
\text { et al. } \\
\text { (2003) }\end{array}$ \\
\hline KRSR & $\begin{array}{l}\text { Binds to } \\
\text { transmembrane } \\
\text { proteoglycans }\end{array}$ & $\begin{array}{l}\text { Selectively increase osteoblast } \\
\text { adhesion with bioadhesive } \\
\text { moiety functionalization }\end{array}$ & $\begin{array}{l}\text { Anderson } \\
\text { et al. } \\
\text { (2009b) }\end{array}$ \\
\hline GAG-PA & $\begin{array}{l}\text { Heparan sulfate- } \\
\text { mimicking peptide }\end{array}$ & $\begin{array}{l}\text { Protein-based extracellular } \\
\text { matrix components, } \\
\text { glycosaminoglycans (GAGs) } \\
\text { regulate bone formation }\end{array}$ & $\begin{array}{l}\text { Kocabey } \\
\text { et al. } \\
\text { (2013) }\end{array}$ \\
\hline $\begin{array}{l}\text { E3-PA+ } \\
\text { Dopa-PA }\end{array}$ & $\begin{array}{l}\text { Noncollagenous } \\
\text { matrix proteins }\end{array}$ & $\begin{array}{l}\text { Mineralization and osteogenic } \\
\text { differentiation }\end{array}$ & $\begin{array}{l}\text { Ceylan } \\
\text { et al. } \\
\text { (2014) }\end{array}$ \\
\hline RADA16 & $\begin{array}{l}\text { Originally designed } \\
\text { as ionic self- } \\
\text { complementary } \\
\text { oligopeptides }\end{array}$ & & $\begin{array}{l}\text { Gelain } \\
\text { et al. } \\
\text { (2006) }\end{array}$ \\
\hline ALK & $\begin{array}{l}\text { Osteogenic growth } \\
\text { peptide }\end{array}$ & $\begin{array}{l}\text { Osteogenic differentiation } \\
\text { of osteoprogenitors }\end{array}$ & \\
\hline DGR & Osteopontin & & \\
\hline PRG & Two-unit RGD motifs & & \\
\hline
\end{tabular}




\subsection{FUTURE PERSPECTIVES}

Bone grafts can offer promising platforms for bone regeneration studies and therapeutic applications by integrating dynamics and functions of different materials to reach high responsivity to stimuli, healing potential, and environmental adaptation. The expansion of knowledge on bone structure and reconstruction at molecular level is continuing to lead to improvement of bone regeneration methods. Yet, further information is required to fill remaining gaps in this area. Particularly, short peptide-mediated regeneration requires more detailed analysis in terms of investigation of new sequences and their cellular activities during skeletal repair to elicit cellularmolecular interactions for developing novel and effective regenerative materials. Further understanding in this area, with the integration of a wide variety of material-based strategies, could be the key to develop integrated and efficient bone regeneration methods. Hence, integration and manipulation of bone regeneration strategies that approximate natural bone cascade can lead to successful treatment of many bone diseases including aging- or genetic-related illnesses and bone traumas (Table 6.1).

\section{REFERENCES}

Aboushelib, M.N., Salem, N.A., Taleb, A.L., and El Moniem, N.M. (2013). Influence of surface nano-roughness on osseointegration of zirconia implants in rabbit femur heads using selective infiltration etching technique. The Journal of Oral Implantology 39, 583-590.

Adell, R. (1985). Tissue integrated prostheses in clinical dentistry. International Dental Journal 35, 259-265.

Albrektsson, T., Dahlin, C., Jemt, T., Sennerby, L., Turri, A., and Wennerberg, A. (2014). Is marginal bone loss around oral implants the result of a provoked foreign body reaction? Clinical Implant Dentistry and Related Research 16, 155-165.

Albrektsson, T. and Wennerberg, A. (2004). Oral implant surfaces: part 1-review focusing on topographic and chemical properties of different surfaces and in vivo responses to them. The International Journal of Prosthodontics 17, 536-543.

Alghamdi, H.S., Bosco, R., van den Beucken, J.J.J.P., Walboomers, X.F., and Jansen, J.A. (2013). Osteogenicity of titanium implants coated with calcium phosphate or collagen type-I in osteoporotic rats. Biomaterials 34, 3747-3757.

Anderson, J.M., Andukuri, A., Lim, D.J., and Jun, H.W. (2009a). Modulating the gelation properties of self-assembling peptide amphiphiles. ACS Nano 3, $3447-3454$. 
Anderson, J.M., Kushwaha, M., Tambralli, A., Bellis, S.L., Camata, R.P., and Jun, H.W. (2009b). Osteogenic differentiation of human mesenchymal stem cells directed by extracellular matrix-mimicking ligands in a biomimetic selfassembled peptide amphiphile nanomatrix. Biomacromolecules 10, 2935-2944.

Anderson, J.M., Vines, J.B., Patterson, J.L., Chen, H., Javed, A., and Jun, H.W. (2011). Osteogenic differentiation of human mesenchymal stem cells synergistically enhanced by biomimetic peptide amphiphiles combined with conditioned medium. Acta Biomaterialia 7, 675-682.

Anselme, K. (2000). Osteoblast adhesion on biomaterials. Biomaterials 21, 667-681.

Arima, Y. and Iwata, H. (2007). Effect of wettability and surface functional groups on protein adsorption and cell adhesion using well-defined mixed self-assembled monolayers. Biomaterials 28, 3074-3082.

Athanasiou, K.A., Zhu, C., Lanctot, D.R., Agrawal, C.M., and Wang, X. (2000). Fundamentals of biomechanics in tissue engineering of bone. Tissue Engineering 6, 361-381.

Bax, B.E., Wozney, J.M., and Ashhurst, D.E. (1999). Bone morphogenetic protein-2 increases the rate of callus formation after fracture of the rabbit tibia. Calcified Tissue International 65, 83-89.

Beddoe, A.H., Darley, P.J., and Spiers, F.W. (1976). Measurements of trabecular bone structure in man. Physics in Medicine and Biology 21, 589-607.

Beertsen, W. and van den Bos, T. (1992). Alkaline phosphatase induces the mineralization of sheets of collagen implanted subcutaneously in the rat. The Journal of Clinical Investigation 89, 1974-1980.

Bjursten, L.M., Rasmusson, L., Oh, S., Smith, G.C., Brammer, K.S., and Jin, S. (2010). Titanium dioxide nanotubes enhance bone bonding in vivo. Journal of Biomedical Materials Research, Part A 92, 1218-1224.

Black, K.C.L., Yi, J., Rivera, J.G., Zelasko-Leon, D.C., and Messersmith, P.B. (2012). Polydopamine-enabled surface functionalization of gold nanorods for cancer cell-targeted imaging and photothermal therapy. Nanomedicine 8, 17-28.

Bobyn, J.D., Pilliar, R.M., Cameron, H.U., and Weatherly, G.C. (1980). The optimum pore size for the fixation of porous-surfaced metal implants by the ingrowth of bone. Clinical Orthopaedics and Related Research, 263-270.

Bosetti, M., Lloyd, A.W., Santin, M., Denyer, S.P., and Cannas, M. (2005). Effects of phosphatidylserine coatings on titanium on inflammatory cells and cellinduced mineralisation in vitro. Biomaterials 26, 7572-7578.

Brandi, M.L. and Collin-Osdoby, P. (2006). Vascular biology and the skeleton. Journal of Bone and Mineral Research 21, 183-192.

Branemark, R., Branemark, P.I., Rydevik, B., and Myers, R.R. (2001). Osseointegration in skeletal reconstruction and rehabilitation: a review. Journal of Rehabilitation Research and Development 38, 175-181. 
ButLer, W.T., ed. (2000). Noncollagenous proteins of bone and dentin: a brief overview (Rosemont IL:AAOS).

Canalis, E., McCarthy, T., and Centrella, M. (1988). Growth factors and the regulation of bone remodeling. The Journal of Clinical Investigation 81, 277-281.

Ceylan, H., Kocabey, S., Tekinay, A.B., and Guler, M.O. (2012). Surface-adhesive and osteogenic self-assembled peptide nanofibers for bioinspired functionalization of titanium surfaces. Soft Matter 8, 3929-3937.

Ceylan, H., Kocabey, S., Unal Gulsuner, H., Balcik, O.S., Guler, M.O., and Tekinay, A.B. (2014). Bone-like mineral nucleating peptide nanofibers induce differentiation of human mesenchymal stem cells into mature osteoblasts. Biomacromolecules 15, 2407-2418.

Ceylan, H., Tekinay, A.B., and Guler, M.O. (2011). Selective adhesion and growth of vascular endothelial cells on bioactive peptide nanofiber functionalized stainless steel surface. Biomaterials 32, 8797-8805.

Ceylan, H., Tekinay, A.B., and Guler, M.O. (2013). Mussel-inspired adhesive interfaces for biomedical applications. In Biological and biomimetic adhesives: challenges and opportunities, R. Santos, N. Aldred, S. Gorb, and P. Flammang, eds. (Cambridge: The Royal Society of Chemistry), pp. 103-116.

Chen, Y., Mak, A.F., Wang, M., and Li, J. (2006). Composite coating of bonelike apatite particles and collagen fibers on poly-L-lactic acid formed through an accelerated biomimetic coprecipitation process. Journal of Biomedical Materials Research Part B: Applied Biomaterials 77, 315-322.

Chien, C.-Y. and Tsai, W.-B. (2013). Poly(dopamine)-assisted immobilization of Arg-Gly-Asp peptides, hydroxyapatite, and bone morphogenic protein-2 on titanium to improve the osteogenesis of bone marrow stem cells. ACS Applied Materials \& Interfaces 5, 6975-6983.

Chim, S.M., Tickner, J., Chow, S.T., Kuek, V., Guo, B., Zhang, G., Rosen, V., Erber, W., and Xu, J. (2013). Angiogenic factors in bone local environment. Cytokine \& Growth Factor Reviews 24, 297-310.

Chollet, C., Chanseau, C., Remy, M., Guignandon, A., Bareille, R., Labrugere, C., Bordenave, L., and Durrieu, M.C. (2009). The effect of RGD density on osteoblast and endothelial cell behavior on RGD-grafted polyethylene terephthalate surfaces. Biomaterials 30, 711-720.

Chug, A., Shukla, S., Mahesh, L., and Jadwani, S. (2013). Osseointegrationmolecular events at the bone-implant interface: a review. Journal of Oral and Maxillofacial Surgery, Medicine, and Pathology 25, 1-4.

Cowan, C.M., Shi, Y.Y., Aalami, O.O., Chou, Y.F., Mari, C., Thomas, R., Quarto, N., Contag, C.H., Wu, B., and Longaker, M.T. (2004). Adipose-derived adult stromal cells heal critical-size mouse calvarial defects. Nature Biotechnology $22,560-567$.

Cui, H., Webber, M.J., and Stupp, S.I. (2010). Self-assembly of peptide amphiphiles: from molecules to nanostructures to biomaterials. Biopolymers 94, 1-18. 
Daculsi, G., Passuti, N., Martin, S., Deudon, C., Legeros, R.Z., and Raher, S. (1990). Macroporous calcium phosphate ceramic for long bone surgery in humans and dogs. Clinical and histological study. Journal of Biomedical Materials Research 24, 379-396.

David, L., Feige, J.J., and Bailly, S. (2009). Emerging role of bone morphogenetic proteins in angiogenesis. Cytokine \& Growth Factor Reviews 20, 203-212.

de Oliveira, P.T. and Nanci, A. (2004). Nanotexturing of titanium-based surfaces upregulates expression of bone sialoprotein and osteopontin by cultured osteogenic cells. Biomaterials 25, 403-413.

Deckers, M.M., van Bezooijen, R.L., van der Horst, G., Hoogendam, J., van Der Bent, C., Papapoulos, S.E., and Lowik, C.W. (2002). Bone morphogenetic proteins stimulate angiogenesis through osteoblast-derived vascular endothelial growth factor A. Endocrinology 143, 1545-1553.

Dee, K.C., Andersen, T.T., and Bizios, R. (1998). Design and function of novel osteoblast-adhesive peptides for chemical modification of biomaterials. Journal of Biomedical Materials Research 40, 371-377.

Dohan Ehrenfest, D.M., Coelho, P.G., Kang, B.-S., Sul, Y.-T., and Albrektsson, T. (2010). Classification of osseointegrated implant surfaces: materials, chemistry and topography. Trends in Biotechnology 28, 198-206.

Ducy, P., Geoffroy, V., and Karsenty, G. (1996). Study of osteoblast-specific expression of one mouse osteocalcin gene: characterization of the factor binding to OSE2. Connective Tissue Research 35, 7-14.

Eanes, E.D. (1989). Biophysical aspects of lipid interaction with mineral: liposome model studies. The Anatomical Record 224, 220-225.

Engel, J., Taylor, W., Paulsson, M., Sage, H., and Hogan, B. (1987). Calcium binding domains and calcium-induced conformational transition of SPARC/ BM-40/osteonectin, an extracellular glycoprotein expressed in mineralized and nonmineralized tissues. Biochemistry 26, 6958-6965.

Englund, E.A., Wang, D., Fujigaki, H., Sakai, H., Micklitsch, C.M., Ghirlando, R., Martin-Manso, G., Pendrak, M.L., Roberts, D.D., Durell, S.R., et al. (2012). Programmable multivalent display of receptor ligands using peptide nucleic acid nanoscaffolds. Nature Communications 3, 614.

Erlebacher, A., Filvaroff, E.H., Ye, J.Q., and Derynck, R. (1998). Osteoblastic responses to TGF-beta during bone remodeling. Molecular Biology of the Cell 9, 1903-1918.

Fang, T.D., Salim, A., Xia, W., Nacamuli, R.P., Guccione, S., Song, H.M., Carano, R.A., Filvaroff, E.H., Bednarski, M.D., Giaccia, A.J., et al. (2005). Angiogenesis is required for successful bone induction during distraction osteogenesis. Journal of Bone and Mineral Research 20, 1114-1124.

Fernandez-Yague, M.A., Abbah, S.A., McNamara, L., Zeugolis, D.I., Pandit, A., and Biggs, M.J. (2014). Biomimetic approaches in bone tissue 
engineering: integrating biological and physicomechanical strategies. Advanced Drug Delivery Reviews 84, 1-29.

Ferrara, N., Gerber, H.P., and LeCouter, J. (2003). The biology of VEGF and its receptors. Nature Medicine 9, 669-676.

Fiedler, J., Roderer, G., Gunther, K.P., and Brenner, R.E. (2002). BMP-2, BMP-4, and PDGF-bb stimulate chemotactic migration of primary human mesenchymal progenitor cells. Journal of Cellular Biochemistry 87, 305-312.

Filmon, R., Grizon, F., Basle, M.F., and Chappaard, D. (2002). Effects of negatively charged groups (carboxymethyl) on the calcification of poly(2-hydroxyethyl methacrylate). Biomaterials 23, 3053-3059.

Fratzl-Zelman, N., Fratzl, P., Horandner, H., Grabner, B., Varga, F., Ellinger, A., and Klaushofer, K. (1998). Matrix mineralization in MC3T3-E1 cell cultures initiated by beta-glycerophosphate pulse. Bone 23, 511-520.

Gailit, J., Clarke, C., Newman, D., Tonnesen, M.G., Mosesson, M.W., and Clark, R.A. (1997). Human fibroblasts bind directly to fibrinogen at RGD sites through integrin alpha(v)beta3. Experimental Cell Research 232, 118-126.

Garcia, A.J. and Reyes, C.D. (2005). Bio-adhesive surfaces to promote osteoblast differentiation and bone formation. Journal of Dental Research 84, 407-413.

Gelain, F., Bottai, D., Vescovi, A., and Zhang, S. (2006). Designer self-assembling peptide nanofiber scaffolds for adult mouse neural stem cell 3-dimensional cultures. PLoS One 1, e119.

Gerber, H.P., Vu, T.H., Ryan, A.M., Kowalski, J., Werb, Z., and Ferrara, N. (1999). VEGF couples hypertrophic cartilage remodeling, ossification and angiogenesis during endochondral bone formation. Nature Medicine 5, 623-628.

Gittens, R.A., Olivares-Navarrete, R., Schwartz, Z., and Boyan, B.D. (2014). Implant osseointegration and the role of microroughness and nanostructures: lessons for spine implants. Acta Biomaterialia 10, 3363-3371.

Glimcher, M.J. (1992). The nature of the mineral component of bone and the mechanisms of calcification (New York: Raven Press).

Globus, R.K., Plouet, J., and Gospodarowicz, D. (1989). Cultured bovine bone cells synthesize basic fibroblast growth factor and store it in their extracellular matrix. Endocrinology 124, 1539-1547.

Goldstein, S.A., Wilson, D.L., Sonstegard, D.A., and Matthews, L.S. (1983). The mechanical properties of human tibial trabecular bone as a function of metaphyseal location. Journal of Biomechanics 16, 965-969.

Gowen, M., Wood, D.D., Ihrie, E.J., Mcguire, M.K.B., and Russell, R.G.G. (1983). An interleukin-1 like factor stimulates bone-resorption in vitro. Nature 306, 378-380.

Guler, M.O., Hsu, L., Soukasene, S., Harrington, D.A., Hulvat, J.F., and Stupp, S.I. (2006). Presentation of RGDS epitopes on self-assembled nanofibers of branched peptide amphiphiles. Biomacromolecules 7, 1855-1863. 
Hanada, K., Dennis, J.E., and Caplan, A.I. (1997). Stimulatory effects of basic fibroblast growth factor and bone morphogenetic protein-2 on osteogenic differentiation of rat bone marrow-derived mesenchymal stem cells. Journal of Bone and Mineral Research 12, 1606-1614.

Harbers, G.M. and Healy, K.E. (2005). The effect of ligand type and density on osteoblast adhesion, proliferation, and matrix mineralization. Journal of Biomedical Materials Research, Part A 75, 855-869.

Hartgerink, J.D., Beniash, E., and Stupp, S.I. (2001). Self-assembly and mineralization of peptide-amphiphile nanofibers. Science 294, 1684-1688.

Hauge, E.M., Qvesel, D., Eriksen, E.F., Mosekilde, L., and Melsen, F. (2001). Cancellous bone remodeling occurs in specialized compartments lined by cells expressing osteoblastic markers. Journal of Bone and Mineral Research 16, 1575-1582.

Hauschka, P.V., Mavrakos, A.E., Iafrati, M.D., Doleman, S.E., and Klagsbrun, M. (1986). Growth-factors in bone-matrix - isolation of multiple types by affinitychromatography on heparin-Sepharose. Journal of Biological Chemistry 261, 2665-2674.

He, C. and Chen, X. (2005). Transcription regulation of the vegf gene by the BMP/Smad pathway in the angioblast of zebrafish embryos. Biochemical and Biophysical Research Communications 329, 324-330.

Hennessy, K.M., Pollot, B.E., Clem, W.C., Phipps, M.C., Sawyer, A.A., Culpepper, B.K., and Bellis, S.L. (2009). The effect of collagen I mimetic peptides on mesenchymal stem cell adhesion and differentiation, and on bone formation at hydroxyapatite surfaces. Biomaterials 30, 1898-1909.

Henriksen, K., Karsdal, M., Delaisse, J.M., and Engsig, M.T. (2003). RANKL and vascular endothelial growth factor (VEGF) induce osteoclast chemotaxis through an ERK1/2-dependent mechanism. Journal of Biological Chemistry 278, 48745-48753.

Hoption Cann, S., van Netten, J., and van Netten, C. (2003). Dr. William Coley and tumour regression: a place in history or in the future. Postgraduate Medical Journal 79, 672-680.

Horii, A., Wang, X., Gelain, F., and Zhang, S. (2007). Biological designer selfassembling peptide nanofiber scaffolds significantly enhance osteoblast proliferation, differentiation and 3-D migration. PLoS One 2, e190.

Hunter, G.K., Hauschka, P.V., Poole, A.R., Rosenberg, L.C., and Goldberg, H.A. (1996). Nucleation and inhibition of hydroxyapatite formation by mineralized tissue proteins. The Biochemical Journal 317 (Pt 1), 59-64.

Hynes, R.O. (1992). Integrins: versatility, modulation, and signaling in cell adhesion. Cell 69, 11-25.

Kalajzic, I., Staal, A., Yang, W.-P., Wu, Y., Johnson, S.E., Feyen, J.H.M., Krueger, W., Maye, P., Yu, F., Zhao, Y., et al. (2005). Expression profile of 
osteoblast lineage at defined stages of differentiation. Journal of Biological Chemistry 280, 24618-24626.

Kanczler, J.M. and Oreffo, R.O. (2008). Osteogenesis and angiogenesis: the potential for engineering bone. European Cells \& Materials 15, 100-114.

Kang, S.M., Hwang, N.S., Yeom, J., Park, S.Y., Messersmith, P.B., Choi, I.S., Langer, R., Anderson, D.G., and Lee, H. (2012). One-step multipurpose surface functionalization by adhesive catecholamine. Advanced Functional Materials 22, 2949-2955.

Katsamenis, O.L., Chong, H.M.H., Andriotis, O.G., and Thurner, P.J. (2013). Load-bearing in cortical bone microstructure: selective stiffening and heterogeneous strain distribution at the lamellar level. Journal of the Mechanical Behavior of Biomedical Materials 17, 152-165.

Khan, S.N., Ramachandran, M., Senthil Kumar, S., Krishnan, V., and Sundaram, R. (2012). Osseointegration and more-a review of literature. Indian Journal of Dentistry 3, 72-76.

Kielty, C.M. and Grant, M. E. (2002). The collagen family: structure, assembly, and organization in the extracellular matrix. In Connective tissue and its heritable disorders: molecular, genetic, and medical aspects, 2nd edn. (eds P. M. Royce and B. Steinmann, John Wiley \& Sons, Inc., Hoboken).

Klein, S., Giancotti, F.G., Presta, M., Albelda, S.M., Buck, C.A., and Rifkin, D.B. (1993). Basic fibroblast growth factor modulates integrin expression in microvascular endothelial cells. Molecular Biology of the Cell 4, 973-982.

Kocabey, S., Ceylan, H., Tekinay,A.B., and Guler, M.O.(2013). Glycosaminoglycan mimetic peptide nanofibers promote mineralization by osteogenic cells. Acta Biomaterialia 9, 9075-9085.

Lavenus, S., Louarn, G., and Layrolle, P. (2010). Nanotechnology and dental implants. International Journal of Biomaterials 2010, 9.

Layrolle, P. (2011). 1.112-Calcium phosphate coatings. In Comprehensive biomaterials, D. Paul, ed. (Oxford: Elsevier), pp. 223-229.

Le Guéhennec, L., Soueidan, A., Layrolle, P., and Amouriq, Y. (2007). Surface treatments of titanium dental implants for rapid osseointegration. Dental Materials 23, 844-854.

Lee, D.H., Park, B.J., Lee, M.S., Lee, J.W., Kim, J.K., Yang, H.C., and Park, J.C. (2006). Chemotactic migration of human mesenchymal stem cells and MC3T3E1 osteoblast-like cells induced by COS-7 cell line expressing rhBMP-7. Tissue Engineering 12, 1577-1586.

Lee, H., Dellatore, S.M., Miller, W.M., and Messersmith, P.B. (2007). Musselinspired surface chemistry for multifunctional coatings. Science 318, 426-430.

LeGeros, R.Z. (2008). Calcium phosphate-based osteoinductive materials. Chemical Reviews 108, 4742-4753. 
Li, G., Cui, Y., McIlmurray, L., Allen, W.E., and Wang, H. (2005). rhBMP-2, rhVEGF(165), rhPTN and thrombin-related peptide, TP508 induce chemotaxis of human osteoblasts and microvascular endothelial cells. Journal of Orthopaedic Research 23, 680-685.

Li, Q., Wang, J., Shahani, S., Sun, D.D., Sharma, B., Elisseeff, J.H., and Leong, K.W. (2006). Biodegradable and photocrosslinkable polyphosphoester hydrogel. Biomaterials 27, 1027-1034.

Lim, Y.-b., Moon, K.-S., and Lee, M. (2009). Recent advances in functional supramolecular nanostructures assembled from bioactive building blocks. Chemical Society Reviews 38, 925-934.

Linder, L. (1989). Osseointegration of metallic implants. I. Light microscopy in the rabbit. Acta Orthopaedica Scandinavica 60, 129-134.

Mackie, E.J. (2003). Osteoblasts: novel roles in orchestration of skeletal architecture. The International Journal of Biochemistry \& Cell Biology 35, 1301-1305.

Maes, C., Carmeliet, P., Moermans, K., Stockmans, I., Smets, N., Collen, D., Bouillon, R., and Carmeliet, G. (2002). Impaired angiogenesis and endochondral bone formation in mice lacking the vascular endothelial growth factor isoforms VEGF164 and VEGF188. Mechanisms of Development 111, 61-73.

Maes, C., Stockmans, I., Moermans, K., Van Looveren, R., Smets, N., Carmeliet, P., Bouillon, R., and Carmeliet, G. (2004). Soluble VEGF isoforms are essential for establishing epiphyseal vascularization and regulating chondrocyte development and survival. The Journal of Clinical Investigation 113, 188-199.

Marinucci, L., Balloni, S., Becchetti, E., Belcastro, S., Guerra, M., Calvitti, M., Lilli, C., Calvi, E.M., and Locci, P. (2006). Effect of titanium surface roughness on human osteoblast proliferation and gene expression in vitro. The International Journal of Oral \& Maxillofacial Implants 21, 719-725.

Mata, A., Hsu, L., Capito, R., Aparicio, C., Henrikson, K., and Stupp, S.I. (2009). Micropatterning of bioactive self-assembling gels. Soft Matter 5, 1228-1236.

Maurer, P., Hohenester, E., and Engel, J. (1996). Extracellular calcium-binding proteins. Current Opinion in Cell Biology 8, 609-617.

Mavrogenis, A.F., Papagelopoulos, P.J., and Babis, G.C. (2011). Osseointegration of cobalt-chrome alloy implants. Journal of Long-Term Effects of Medical Implants 21, 349-358.

Mayr-Wohlfart, U., Waltenberger, J., Hausser, H., Kessler, S., Gunther, K.P., Dehio, C., Puhl, W., and Brenner, R.E. (2002). Vascular endothelial growth factor stimulates chemotactic migration of primary human osteoblasts. Bone 30, 472-477.

Mehrotra, M., Krane, S.M., Walters, K., and Pilbeam, C. (2004). Differential regulation of platelet-derived growth factor stimulated migration and proliferation in osteoblastic cells. Journal of Cellular Biochemistry 93, 741-752. 
Melo, M.D., Shafie, H., and Obeid, G. (2006). Implant survival rates for oral and maxillofacial surgery residents: a retrospective clinical review with analysis of resident level of training on implant survival. Journal of Oral and Maxillofacial Surgery 64, 1185-1189.

Mendonca, G., Mendonca, D.B., Simoes, L.G., Araujo, A.L., Leite, E.R., Duarte, W.R., Aragao, F.J., and Cooper, L.F. (2009). The effects of implant surface nanoscale features on osteoblast-specific gene expression. Biomaterials 30 , 4053-4062.

Mistry, A.S. and Mikos, A.G. (2005). Tissue engineering strategies for bone regeneration. Advances in Biochemical Engineering/Biotechnology $94,1-22$.

Mizuno, M., Fujisawa, R., and Kuboki, Y. (2000). Type I collagen-induced osteoblastic differentiation of bone-marrow cells mediated by collagen-alpha2beta1 integrin interaction. Journal of Cellular Physiology 184, 207-213.

Mizuno, M. and Kuboki, Y. (2001). Osteoblast-related gene expression of bone marrow cells during the osteoblastic differentiation induced by type I collagen. Journal of Biochemistry 129, 133-138.

Mohan, S. and Baylink, D.J. (1991). Bone growth factors. Clinical Orthopaedics and Related Research 263, 30-48.

Montero, A., Okada, Y., Tomita, M., Ito, M., Tsurukami, H., Nakamura, T., Doetschman, T., Coffin, J.D., and Hurley, M.M. (2000). Disruption of the fibroblast growth factor-2 gene results in decreased bone mass and bone formation. The Journal of Clinical Investigation 105, 1085-1093.

Mundi, S., Pindiprolu, B., Simunovic, N., and Bhandari, M. (2014). Similar mortality rates in hip fracture patients over the past 31 years. Acta Orthopaedica 85, 54-59.

Nair, A.K., Gautieri, A., Chang, S.W., and Buehler, M.J. (2013). Molecular mechanics of mineralized collagen fibrils in bone. Nature Communications 4, 1724.

Nelson, M., Balasundaram, G., and Webster, T.J. (2006). Increased osteoblast adhesion on nanoparticulate crystalline hydroxyapatite functionalized with KRSR. International Journal of Nanomedicine 1, 339-349.

Niece, K.L., Hartgerink, J.D., Donners, J.J.J.M., and Stupp, S.I. (2003). Selfassembly combining two bioactive peptide-amphiphile molecules into nanofibers by electrostatic attraction. Journal of the American Chemical Society $125,7146-7147$.

Oldberg, A., Franzen, A., and Heinegard, D. (1986). Cloning and sequence analysis of rat bone sialoprotein (osteopontin) cDNA reveals an Arg-Gly-Asp cell-binding sequence. Proceedings of the National Academy of Sciences of the United States of America 83, 8819-8823.

Oldberg, A., Franzen, A., Heinegard, D., Pierschbacher, M., and Ruoslahti, E. (1988). Identification of a bone sialoprotein receptor in osteosarcoma cells. The Journal of Biological Chemistry 263, 19433-19436. 
Olivares-Navarrete, R., Hyzy, S.L., Berg, M.E., Schneider, J.M., Hotchkiss, K., Schwartz, Z., and Boyan, B.D. (2014). Osteoblast lineage cells can discriminate microscale topographic features on titanium-aluminum-vanadium surfaces. Annals of Biomedical Engineering 42, 2551-2561.

Olivares-Navarrete, R., Raz, P., Zhao, G., Chen, J., Wieland, M., Cochran, D.L., Chaudhri, R.A., Ornoy, A., Boyan, B.D., and Schwartz, Z. (2008). Integrin $\alpha 2 \beta 1$ plays a critical role in osteoblast response to micron-scale surface structure and surface energy of titanium substrates. Proceedings of the National Academy of Sciences 105, 15767-15772.

Palmer, L.C., Newcomb, C.J., Kaltz, S.R., Spoerke, E.D., and Stupp, S.I. (2008). Biomimetic systems for hydroxyapatite mineralization inspired by bone and enamel. Chemistry Review 108, 4754-4783.

Pampena, D.A., Robertson, K.A., Litvinova, O., Lajoie, G., Goldberg, H.A., and Hunter, G.K. (2004). Inhibition of hydroxyapatite formation by osteopontin phosphopeptides. The Biochemical Journal 378, 1083-1087.

Penarrocha-Diago, M., Demarchi, C.L., Maestre-Ferrin, L., Carrillo, C., Penarrocha-Oltra, D., and Penarrocha-Diago, M.A. (2012). A retrospective comparison of 1,022 implants: immediate versus nonimmediate. The International Journal of Oral \& Maxillofacial Implants 27, 421-427.

Peng, H., Usas, A., Olshanski, A., Ho, A.M., Gearhart, B., Cooper, G.M., and Huard, J. (2005). VEGF improves, whereas sFlt1 inhibits, BMP2-induced bone formation and bone healing through modulation of angiogenesis. Journal of Bone and Mineral Research 20, 2017-2027.

Pitaru, S., Kotev-Emeth, S., Noff, D., Kaffuler, S., and Savion, N. (1993). Effect of basic fibroblast growth factor on the growth and differentiation of adult stromal bone marrow cells: enhanced development of mineralized bone-like tissue in culture. Journal of Bone and Mineral Research 8, 919-929.

Popov, C., Radic, T., Haasters, F., Prall, W.C., Aszodi, A., Gullberg, D., Schieker, M., and Docheva, D. (2011). Integrins [alpha]2[beta]1 and [alpha]11[beta]1 regulate the survival of mesenchymal stem cells on collagen I. Cell Death and Disease 2, e186.

Puleo, D.A. and Bizios, R. (1991). RGDS tetrapeptide binds to osteoblasts and inhibits fibronectin-mediated adhesion. Bone 12, 271-276.

Puleo, D.A. and Nanci, A. (1999). Understanding and controlling the boneimplant interface. Biomaterials 20, 2311-2321.

Pytela, R., Pierschbacher, M.D., Argraves, S., Suzuki, S., and Ruoslahti, E. (1987). Arginine-glycine-aspartic acid adhesion receptors. Methods in Enzymology $144,475-489$.

Qi, H., Aguiar, D.J., Williams, S.M., La Pean, A., Pan, W., and Verfaillie, C.M. (2003). Identification of genes responsible for osteoblast differentiation from human mesodermal progenitor cells. Proceedings of the National Academy of Sciences 100, 3305-3310. 
Raggio, C.L., Boyan, B.D., and Boskey, A.L. (1986). In vivo hydroxyapatite formation induced by lipids. Journal of Bone and Mineral Research 1, 409-415.

Reznikov, N., Shahar, R., and Weiner, S. (2014). Bone hierarchical structure in three dimensions. Acta Biomaterialia 10, 3815-3826.

Roberts, J.E., Bonar, L.C., Griffin, R.G., and Glimcher, M.J. (1992). Characterization of very young mineral phases of bone by solid state 31 phosphorus magic angle sample spinning nuclear magnetic resonance and $\mathrm{X}$-ray diffraction. Calcified Tissue International 50, 42-48.

Ruardy, T.G., Schakenraad, J.M., van der Mei, H.C., and Busscher, H.J. (1995). Adhesion and spreading of human skin fibroblasts on physicochemically characterized gradient surfaces. Journal of Biomedical Materials Research 29, 1415-1423.

Sato, Y., Shimada, T., and Takaki, R. (1991). Autocrinological role of basic fibroblast growth factor on tube formation of vascular endothelial cells in vitro. Biochemical and Biophysical Research Communications 180, 1098-1102.

Schwarz, F., Wieland, M., Schwartz, Z., Zhao, G., Rupp, F., Geis-Gerstorfer, J., Schedle, A., Broggini, N., Bornstein, M.M., Buser, D., et al. (2009). Potential of chemically modified hydrophilic surface characteristics to support tissue integration of titanium dental implants. Journal of Biomedical Materials Research Part B: Applied Biomaterials 88, 544-557.

Seghezzi, G., Patel, S., Ren, C.J., Gualandris, A., Pintucci, G., Robbins, E.S., Shapiro, R.L., Galloway, A.C., Rifkin, D.B., and Mignatti, P. (1998). Fibroblast growth factor-2 (FGF-2) induces vascular endothelial growth factor (VEGF) expression in the endothelial cells of forming capillaries: an autocrine mechanism contributing to angiogenesis. The Journal of Cell Biology 141, 1659-1673.

Shao, E.S., Lin, L., Yao, Y., and Bostrom, K.I. (2009). Expression of vascular endothelial growth factor is coordinately regulated by the activin-like kinase receptors 1 and 5 in endothelial cells. Blood 114, 2197-2206.

Shu, X.Z., Ghosh, K., Liu, Y., Palumbo, F.S., Luo, Y., Clark, R.A., and Prestwich, G.D. (2004). Attachment and spreading of fibroblasts on an RGD peptidemodified injectable hyaluronan hydrogel. Journal of Biomedical Materials Research, Part A 68, 365-375.

Sikavitsas, V.I., Temenoff, J.S., and Mikos, A.G. (2001). Biomaterials and bone mechanotransduction. Biomaterials 22, 2581-2593.

Silva, G.A., Czeisler, C., Niece, K.L., Beniash, E., Harrington, D.A., Kessler, J.A., and Stupp, S.I. (2004). Selective differentiation of neural progenitor cells by high-epitope density nanofibers. Science 303, 1352-1355.

Simonis, P., Dufour, T., and Tenenbaum, H. (2010). Long-term implant survival and success: a 10-16-year follow-up of non-submerged dental implants. Clinical Oral Implants Research 21, 772-777. 
Smalley, W.M., Shapiro, P.A., Hohl, T.H., Kokich, V.G., and Branemark, P.I. (1988). Osseointegrated titanium implants for maxillofacial protraction in monkeys. American Journal of Orthodontics and Dentofacial Orthopedics 94, 285-295.

Sojo, K., Sawaki, Y., Hattori, H., Mizutani, H., and Ueda, M. (2005). Immunohistochemical study of vascular endothelial growth factor (VEGF) and bone morphogenetic protein-2,-4 (BMP-2,-4) on lengthened rat femurs. Journal of Cranio-Maxillofacial Surgery 33, 238-245.

Song, W. and Mano, J.F. (2013). Interactions between cells or proteins and surfaces exhibiting extreme wettabilities. Soft Matter 9, 2985-2999.

Sousa, S.R., Lamghari, M., Sampaio, P., Moradas-Ferreira, P., and Barbosa, M.A. (2008). Osteoblast adhesion and morphology on $\mathrm{TiO}_{2}$ depends on the competitive preadsorption of albumin and fibronectin. Journal of Biomedical Materials Research, Part A 84, 281-290.

Southam, J.C. and Selwyn, P. (1970). Structural changes around screws used in the treatment of fractured human mandibles. British Journal of Oral Surgery 8 , 211-221.

Sporn, M.B., Roberts, A.B., Wakefield, L.M., and Assoian, R.K. (1986). Transforming growth factor-beta: biological function and chemical structure. Science 233, 532-534.

Staatz, W.D., Fok, K.F., Zutter, M.M., Adams, S.P., Rodriguez, B.A., and Santoro, S.A. (1991). Identification of a tetrapeptide recognition sequence for the alpha 2 beta 1 integrin in collagen. Journal of Biological Chemistry 266, 7363-7367.

Stancu, I.C., Filmon, R., Grizon, F., Zaharia, C., Cincu, C., Basle, M.F., and Chappard, D. (2004). The in vivo calcification capacity of a copolymer, based on methacryloyloxyethyl phosphate, does not favor osteoconduction. Journal of Biomedical Materials Research, Part A 69, 584-589.

Storrie, H. and Stupp, S.I. (2005). Cellular response to zinc-containing organoapatite: an in vitro study of proliferation, alkaline phosphatase activity and biomineralization. Biomaterials 26, 5492-5499.

Street, J., Bao, M., deGuzman, L., Bunting, S., Peale, F.V., Jr., Ferrara, N., Steinmetz, H., Hoeffel, J., Cleland, J.L., Daugherty, A., et al. (2002). Vascular endothelial growth factor stimulates bone repair by promoting angiogenesis and bone turnover. Proceedings of the National Academy of Sciences of the United States of America 99, 9656-9661.

Sur, S., Pashuck, E.T., Guler, M.O., Ito, M., Stupp, S.I., and Launey, T. (2012). A hybrid nanofiber matrix to control the survival and maturation of brain neurons. Biomaterials 33, 545-555.

Tan, J., Gemeinhart, R.A., Ma, M., and Saltzman, W.M. (2005). Improved cell adhesion and proliferation on synthetic phosphonic acid-containing hydrogels. Biomaterials 26, 3663-3671. 
Tanahashi, M. and Matsuda, T. (1997). Surface functional group dependence on apatite formation on self-assembled monolayers in a simulated body fluid. Journal of Biomedical Materials Research 34, 305-315.

Tang, Y., Wu, X., Lei, W., Pang, L., Wan, C., Shi, Z., Zhao, L., Nagy, T.R., Peng, X., Hu, J., et al. (2009). TGF- $\beta 1$-induced migration of bone mesenchymal stem cells couples bone resorption with formation. Nature Medicine 15, 757-765.

Tashiro, K., Sephel, G.C., Weeks, B., Sasaki, M., Martin, G.R., Kleinman, H.K., and Yamada, Y. (1989). A synthetic peptide containing the IKVAV sequence from the A chain of laminin mediates cell attachment, migration, and neurite outgrowth. The Journal of Biological Chemistry 264, 16174-16182.

Traub, W., Arad, T., and Weiner, S. (1989). Three-dimensional ordered distribution of crystals in turkey tendon collagen fibers. Proceedings of the National Academy of Sciences of the United States of America 86, 9822-9826.

Traub, W., Arad, T., and Weiner, S. (1992). Origin of mineral crystal growth in collagen fibrils. Matrix 12, 251-255.

Triffit, J.T. (1980). The organic matrix of bone tissue (Philadelphia, PA: J. B. Lippincott).

Unal Gulsuner, H., Atalay Gengec, N., Kilinc, M., Erbil, H.Y., and Tekinay, A.B. (2015). Osteoselection supported by phase separated polymer blend films. Journal of Biomedical Materials Research, Part A 103, 154-161.

Urist, M.R. (1965). Bone: formation by autoinduction. Science 150, 893-899.

Urist, M.R., DeLange, R.J., and Finerman, G.A. (1983). Bone cell differentiation and growth factors. Science 220, 680-686.

Vanhegan, I.S., Malik, A.K., Jayakumar, P., Ul Islam, S., and Haddad, F.S. (2012). A financial analysis of revision hip arthroplasty: the economic burden in relation to the national tariff. The Journal of Bone and Joint Surgery 94, 619-623.

Vasak, C., Busenlechner, D., Schwarze, U.Y., Leitner, H.F., Munoz Guzon, F., Hefti, T., Schlottig, F., and Gruber, R. (2014). Early bone apposition to hydrophilic and hydrophobic titanium implant surfaces: a histologic and histomorphometric study in minipigs. Clinical Oral Implants Research 25, 1378-1385.

von Wilmowsky, C., Moest, T., Nkenke, E., Stelzle, F., and Schlegel, K.A. (2014). Implants in bone: part I. A current overview about tissue response, surface modifications and future perspectives. Oral and Maxillofacial Surgery 18, 243-257.

Wang, X., Tolba, E., Schroder, H.C., Neufurth, M., Feng, Q., Diehl-Seifert, B., and Muller, W.E. (2014). Effect of bioglass on growth and biomineralization of SaOS-2 cells in hydrogel after 3D cell bioprinting. PLoS One 9, e112497.

Wazen, J.J., Gupta, R., Ghossaini, S., Spitzer, J., Farrugia, M., and Tjellstrom, A. (2007). Osseointegration timing for Baha system loading. The Laryngoscope $117,794-796$. 
Webber, M.J., Tongers, J., Renault, M.A., Roncalli, J.G., Losordo, D.W., and Stupp, S.I. (2010). Development of bioactive peptide amphiphiles for therapeutic cell delivery. Acta Biomaterialia 6, 3-11.

Weiner, S. and Traub, W. (1986). Organization of hydroxyapatite crystals within collagen fibrils. FEBS Letters 206, 262-266.

Wilson, C.J., Clegg, R.E., Leavesley, D.I., and Pearcy, M.J. (2005). Mediation of biomaterial-cell interactions by adsorbed proteins: a review. Tissue Engineering $11,1-18$.

Wozney, J.M. and Rosen, V. (1998). Bone morphogenetic protein and bone morphogenetic protein gene family in bone formation and repair. Clinical Orthopaedics and Related Research 346, 26-37.

Wuttke, M., Muller, S., Nitsche, D.P., Paulsson, M., Hanisch, F.G., and Maurer, P. (2001). Structural characterization of human recombinant and bone-derived bone sialoprotein. Functional implications for cell attachment and hydroxyapatite binding. The Journal of Biological Chemistry 276, 36839-36848.

Yasuda, H., Shima, N., Nakagawa, N., Yamaguchi, K., Kinosaki, M., Mochizuki, S., Tomoyasu, A., Yano, K., Goto, M., Murakami, A., et al. (1998). Osteoclast differentiation factor is a ligand for osteoprotegerin/osteoclastogenesis-inhibitory factor and is identical to TRANCE/RANKL. Proceedings of the National Academy of Sciences of the United States of America 95, 3597-3602.

Yeo, I.S. (2014). Reality of dental implant surface modification: a short literature review. The Open Biomedical Engineering Journal 8, 114-119.

Yoo, S.Y., Kobayashi, M., Lee, P.P., and Lee, S.-W. (2011). Early osteogenic differentiation of mouse preosteoblasts induced by collagen-derived DGEApeptide on nanofibrous phage tissue matrices. Biomacromolecules 12, 987-996.

Young, M.F., Kerr, J.M., Ibaraki, K., Heegaard, A.M., and Robey, P.G. (1992). Structure, expression, and regulation of the major noncollagenous matrix proteins of bone. Clinical Orthopaedics and Related Research 281, 275-294.

Yuan, H., Fernandes, H., Habibovic, P., de Boer, J., Barradas, A.M.C., de Ruiter, A., Walsh, W.R., van Blitterswijk, C.A., and de Bruijn, J.D. (2010). Osteoinductive ceramics as a synthetic alternative to autologous bone grafting. Proceedings of the National Academy of Sciences United States of America 107, 13614-13619.

Zhang, S. (2003). Fabrication of novel biomaterials through molecular self-assembly. Nature Biotechnology 21, 1171-1178.

Zhang, W-M, Käpylä, J., Puranen, J.S., Knight, C.G., Tiger, C.F., Pentikäinen O.T., Johnson, M.S., Farndale, R.W., Heino, J. and Gullberg. D. (2003) alpha-11 beta-1 Integrin recognizes the GFOGER sequence in interstitial collagens. J. Biol. Chem. 278, 7270-7277. 